\title{
PERANCANGAN INTERIOR KARANGANYAR MUSIC CENTRE DI KABUPATEN KARANGANYAR
}

\author{
Isman Prasetyo Sukarno', R.Ersnathan Budi P. ${ }^{2}$ \\ Program Studi Desain Interior, Fakultas Seni Rupa dan Desain, \\ Institut Seni Indonesia (ISI) Surakarta \\ 1Email: Izman13@yahoo.com \\ 2Email: Ernest.prasetyo@gmail.com
}

\section{ABSTRACT}

Karanganyar Music Center is a place that has become a center for overall music activities in terms of education, performances, information and other musical applications with the aim of developing community appreciation for music supported by supporting facilities. The design of the interior of the Music Center in Karanganyar Regency will raise the typical batik theme of Karanganyar Regency, the Tirta Intan Pari batik motif as a symbolism of Karanganyar Regency's identity, which is packaged in a postmodern style. The design of the Karanganyar Music Center takes place in the middle of the Karanganyar Regency, namely on Jalan Raya Solo-Karanganyar. The selection of this location is considered strategic, easy to reach and also currently has become the center of Karanganyar Community activities, this area is also used Car Free Day every Sunday morning.

Keywords: Karanganyar, Music Center, Batik Karanganyar, Batik Tirta Intanpari, Interior Music Center

\section{PENDAHULUAN}

Kabupaten Karanganyar merupakan salah satu Kabupaten di Provinsi Jawa Tengah dengan Pusat administrasi berlokasi di Karanganyar. Kabupaten Karanganyar terletak di provinsi Jawa Tengah bagian timur. Letak geografis dan kondisi alam pegunungan merupakan kelebihan tersendiri bagi Kabupaten Karanganyar. Karanganyar adalah sebuah Kabupaten dengan potensi wisata yang sangat besar dimana tersedia bentangan alam pegunungan lereng lawu yang indah dengan potensi air terjun, hutan, kesejukan udara, kesuburan tanah berpadu indah dengan banyaknya berbagai situs budaya.

Wilayah Karanganyar yang tergolong luas mempengaruhi faktor keberagaman seni dan budaya masyarakat di Kabupaten Karanganyar. Faktor seni adalah suatu daya tarik tersendiri dari sebuah wilayah. Musik dan seni dipercaya sebagai alat yang menjembatani berbagai golongan masyarakat baik dimasa dulu ataupun dimasa kini.
Karena seni dapat dinikmati secara universal. Hasil karya seni tradisional adalah salah satu jenis seni yang sampai sekarang masih sangat banyak dinikmati. Seni tradisional merupakan hasil olah pemikiran masyarakat sekitar atau local genius yang dikembangkan bersama sebagai wujud identitas masyarakat. Seni musik berhubungan dengan bunyi-bunyian, baik suara manusia maupun instrumental. Seni musik juga beraneka ragam, salah satunya adalah musik tradisional. Menurut Sedyawati musik tradisional adalah musik yang digunakan sebagai perwujudan dan nilai budaya yang sesuai dengan tradisi. ${ }^{1}$ Sedangkan menurut Tumbijo musik tradisional adalah seni budaya yang sejak lama turun temurun telah hidup dan berkembang pada daerah tertentu. ${ }^{2}$ Dapat dijelaskan bahwa musik tradisional Karanganyar adalah musik masyarakat yang diwariskan secara turun-temurun

1 Sedyawati, Edy. 1992. Pertumbuhan Seni Pertunjukan. Jakarta: Sinar Harapan. Hal 23

2 Tumbijo, H.B.Dt. (1977). "Minangkabau dalam seputar seni tradisional" (Diktat) SMSR N.Padang, hal13 
dan berkelanjutan pada masyarakat Kabupaten Karanganyar.

Daya tarik wisata budaya terutama dalam hal musik tradisional terlihat dari banyaknya acara pertunjukan kesenian yang digelar di kabupaten ini. ${ }^{3}$ Potensi wisata kesenian di Kabupaten Karanganyar ini tidak lepas dari peran serta sanggar dan paguyuban kesenian yang dibina oleh Dinas Pariwisata dan Kebudayaan Kabupaten Karanganyar.

Di Kabupaten Karanganyar sendiri tercatat ada enam ribu lima puluh sembilan orang yang terbagi dalam dua puluh empat sanggar atau paguyuban kesenian. Dari dua puluh empat jenis kesenian yang terdaftar, banyak diantaranya yang masuk ke dalam kategori kesenian music tradisional, yaitu karawitan, music lesung, orekorek, music bambu / thek-thek, keroncong, rebana, kulintang, dan santi swara / laras madya. ${ }^{4}$

Sangat disayangkan potensi yang dimiliki Kabupaten Karanganyar di bidang kesenian ini belum memiliki sarana dan prasarana yang mewadahi kegiatan pertunjukan kesenian. Permasalahan belum adanya saranaprasarana pertunjukan seni music tradisional Kabupaten Karanganyar terlihat dari berbagai event pertunjukan seni musik tradisional seringkali digelar di tempat terbuka seperti alun-alun atau lapangan. Adanya permasalahan mengenai kurangnya sarana-prasarana yang belum mewadahi sanggar / paguyuban seni musik di Kabupaten Karanganyar inilah yang melatarbelakangi Perancangan Interior Music Centre di Kabupaten Karanganyar ini.

Dasar perencanaan interior Music Centre di Kabupaten Karanganyar dilatar belakangi atas

3 www.karanganyarkab.go.id/ category/pariwisata/seni-budaya-pariwisata/. 21 September 2017

4 "Jenis Kesenian di Kabupaten Karanganyar". Dokumen Kab. Karanganyar 2015 dasar berbagai kebutuhan, diantaranya adalah tempat pertunjukan kesenian music tradisional yang tergabung di bawah Dinas Pariwisata dan Kebudayaan Kabupaten Karanganyar, memerlukan sarana yang mengakomodasi penikmat music dan wisatawan yang ingin menikmati pertunjukan music tradisional khas Kabupaten Karanganyar. Perancangan interior Music Centre di Kabupaten Karanganyar ini akan mengangkat tema batik khas Kabupaten Karanganyar, yaitu motif batik Tirta Intan Pari sebagai simbolisme identitas Kabupaten ini.

Tahapan proses desain pada Perancangan Interior Karanganyar Music Centre Di Kabupaten Karanganyar dapat dilihat pada bagan dibawah ini:

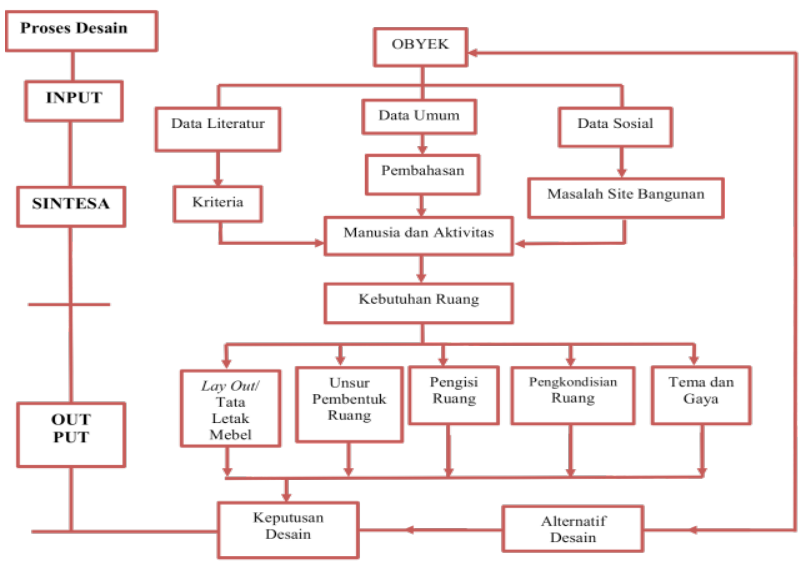

Bagan 1. Bagan tahapan proses desain.

\section{PEMBAHASAN}

\section{A. Pendekatan Pemecahan Desain}

Dalam perencanaan interior Music Centre di Kabupaten Karanganyar ini menggunakan beberapa pendekatan pemecahan desain sebagai berikut:

\section{Pendekatan Fungsi}

Sebuah desain dapat dikatakan 
sebagai desain yang baik apabila mampu memenuhi kebutuhan tidak hanya secara visual ataupun dari segi keamanan, namun juga harus memenuhi aspek fungsi atau fungsional. Seiring dengan perkembangan peradaban manusia, fungsi interior memiliki sejuta makna yang harus ditangkap yang selanjutnya dapat diterjemahkan oleh seorang desainer.

Perencanaan ini bertujuan sebagai sarana berkumpul dan bersantai sembari menikmati pertunjukan music bagi pelaku kesenian, masyarakat umum dan wisatawan, karena itulah proses analisis permasalahan fungsi dalam perancangan ini adalah adanya beberapa fungsi yang tergabung dalam satu ruang yaitu ruang cafe yang sekaligus menjadi ruang auditorium dan panggung pertunjukan music.

\section{Pendekatan Ergonomi}

Untuk memenuhi kebutuhan desain yang mendukung kenyamanan psikis dan fisik perlu adanya pendekatan ergonomi.

Ergonomi berasal dari bahasa Yunani Ergos (bekerja) dan Nomos (hukum alam), yang bermakna sebagai ilmu yang meneliti tentang hubungan antara manusia dengan lingkungan kerjanya (the scientific of relationship between man and his working environment). Tujuannya agar pengguna interior dapat mencapai prestasi kerja yang tinggi (efektif) tetapi dalam suasana yang tentram aman dan nyaman. ${ }^{5}$

\section{Pendekatan Gaya Postmodern}

Perancangan interior Karanganyar

Music Centre ini menggunakan gaya postmodern, yang menggabungkan dua

5 (Sastrowinoto, S. (1985).

Meningkatkan Produktivitas Dengan

Ergonomi. Jakarta: Pustaka Binaman

Pressindo.) atau lebih gaya/ide gagasan menjadi suatu kesatuan perancangan interior. Untuk lebih dapat merancang dengan baik, maka diperlukan pendekatan gaya postmodern yang menjelaskan pengertian, batasan, dan ciri khas dari gaya yang akan digunakan dalam perancangan ini.

Post-Modernism adalah istilah untuk menyebut suatu masa atau zaman yang dipakai berbagai disiplin untuk menguraikan bentuk budaya dari suatu titik pandang dan yang berlawanan atau mengganti istilah modernisme. ${ }^{6}$

Secara konseptual nilai-nilai Modernisme dianggap telah terlalu mapan sehingga tidak sesuai lagi dengan keadaan masa kini yang penuh dengan pradigma baru. Sementara, modernisme itu sendiri dianggap telah melunturkan atau menyebabkan de-gradasi nilai-nilai kemanusian, sehingga muncullah gaya postmodern yang kembali mengangkat local genius dan pemikiran-pemikiran individu.

\section{Pendekatan Tema}

Pada perencanaan karanganyar Music Centre diKabupaten Karanganyar, sesuai dengan tujuan perencanaan yang ingin menampilkan nuansa motif batik Tirta Intan Pari, dengan menggunakan pendekatan bentuk dan material dengan gaya interior modern sebagai pedoman dalam perancangan ini. Motif batik Tirta Intan Pari sendiri adalah motif batik karya M. Qomar yang memenangkan lomba batik di kabupaten karanganyar, yang selanjutnya diangkat menjadi batik khas Kabupaten Karanganyar. ${ }^{7}$

6 Julaihi Wahid dan Bhakti Alamsyah, Teori Arsitektur, (Yogjakarta, 2013), hal 58.

7 Harian Joglosemar, Sabtu,

$11 / 10 / 2014$ 
Pemilihan motif batik ini adalah untuk memberikan ciri khas pada perancangan interior Karanganyar Music Centre, sehingga walaupun pengunjung berada di dalam ruangan, namun tetap bisa merasakan ciri khas kabupaten Karanganyar.

\section{B. Ide Perancangan}

Perancangan interior, ada beberapa hal yangharus diperhatikanyaitu harmoni, kesatuan, varietas, dan kontras. Untuk mendapatkan harmoni maka semua elemen interior harus saling berhubungan. Kemudian kesatuan dapat dicapai ketika keterhubungan dari elemen tersebut dapat dilihat sebagai satu kesatuan keindahan, bukan sebagai keindahan masingmasing elemen. Untuk dapat mencapai harmoni dan kesatuan dalam perancangan interior ini maka ide gagasan akan diolah ke dalam bentukbentuk elemen interior. Motif batik khas kabupaten Karanganyar yang akan menjadi ide dasar dari perancangan interior Karanganyar Music Centre ini, yaitu motif batik Tirta Intan Pari. Tema adalah sesuatu yang menjiwai cerita atau sesuatu yang menjadi pokok masalah dalam cerita, motif batik tirta intanpari inilah yang nantinya akan memunculkan tema yang sesuai identitas lokalitas yang khas dari kabupaten karanganyar, hal ini akan dimunculkan dalam bentuk-bentuk unsur pembentuk ruang maupun unsur pengisi ruang yang akan mengadaptasi bentuk-bentuk yang ada pada motif batik lalu ditransformasikan dan dikemas dalam gaya postmodern.

\section{HASIL PEMBAHASAN DESAIN}

Dasar perencanaan interior Music Centre di Kabupaten Karanganyar dilatar belakangi atas dasar berbagai kebutuhan, diantaranya adalah tempat pertunjukan kesenian music tradisional yang tergabung di bawah Dinas Pariwisata dan Kebudayaan Kabupaten Karanganyar, memerlukan sarana yang mengakomodasi penikmat music dan wisatawan yang ingin menikmati pertunjukan music tradisional khas Kabupaten Karanganyar. Perancangan Interior Music Centre di Kabupaten Karanganyar ini mempunyai sasaran desain yaitu untuk para anggota komunitas seni music di Kabupaten Karanganyar, wisatawan domestic, wisatawan mancanegara, maupun masyarakat umum yang menyukai kesenian music khas Kabupaten Karanganyar yang berkunjung ke Kabupaten Karanganyar.

Perancangan interior Music Centre di Kabupaten Karanganyar ini akan mengangkat tema batik khas Kabupaten Karanganyar, yaitu motif batik Tirta Intan Pari sebagai simbolisme identitas Kabupaten ini yang dikemas dengan gaya postmodern. Adapun hasil dari pemilihan alternatif desain yang telah dipaparkan dalam bab sebelumya akan dibahas pada setiap ruang sebagai berikut:

\section{A. Site plan}

Perancangan Karanganyar Music Centre ini akan mengambil lokasi di tengah Kabupaten Karanganyar, yaitu di Jalan Raya SoloKaranganyar. Pemilihan lokasi ini dikarenakan lokasi ini dianggap strategis, mudah dijangkau dan juga saat ini sudah menjadi pusat aktivitas Masyarakat Karanganyar, kawasan ini juga dipakai Car Free Day pada setiap hari minggu pagi.

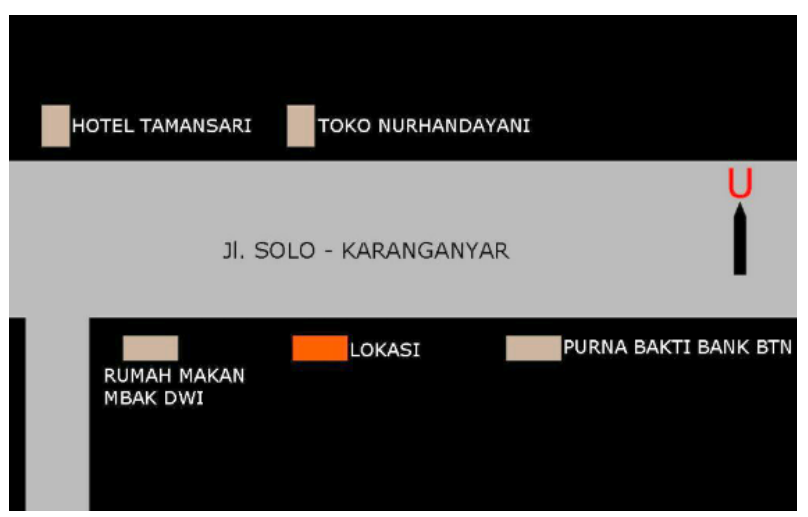


Gambar 2 Site plan Karanganyar Music Centre

\section{B. Skema Warna}

Skema warna yang digunakan pada perancangan interior Karanganyar Music Centre ini mengambil dari batik tirta intan pari, hal ini bertujuan untuk memperkuat identitas Kabupaten Karanganyar pada tema ruang. Skema warna ini kemudian diterapkan pada elemen-elemen ruang dengan pemilihan warna bahan natural dan juga pemilihan warna cat dan fabrikasi yang dipakai dalam perancangan. Skema warna yang akan digunakan adalah sebagai berikut.

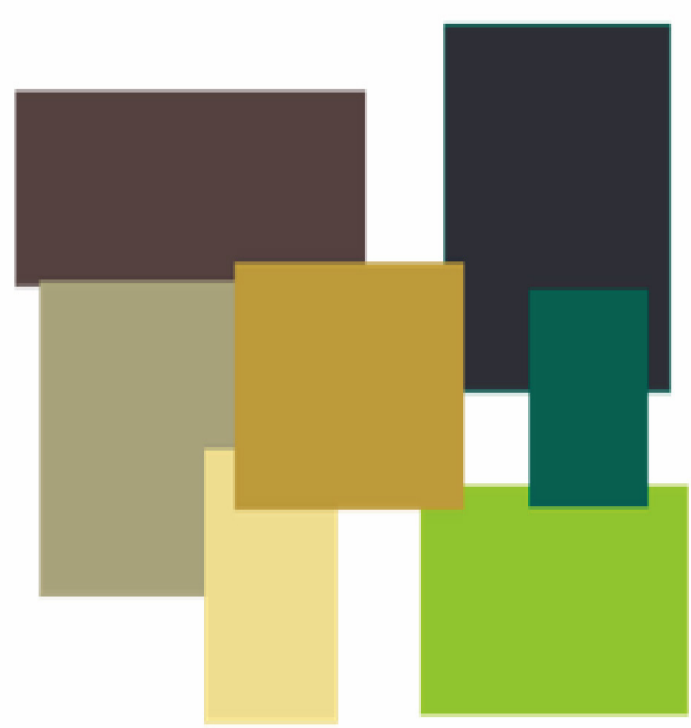

Gambar 3 Skema Warna

\section{Layout}

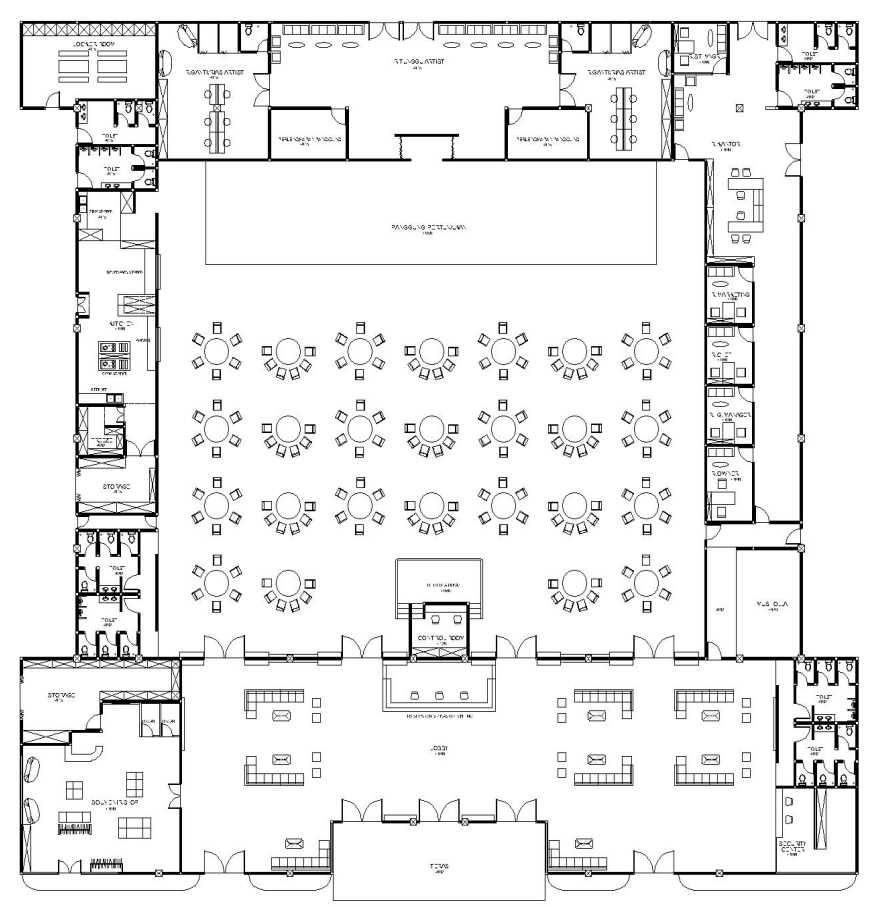

Gambar 4 Layout Terpilih

Layout terpilih pada perancangan interior Karanganyar Music Centre ini telah memenuhi aspek fungsional, fleksibilitas, kenyamanan, dan keamanan. Sehingga dengan desain layout terpilih diharapkan dapat menunjang aktivitas yang akan dilakukan di dalam ruang lingkup garap perancangan.

\section{Hasil Desain dan Pembahasan Desain Lobby}

1. Lantai Lobby Terpilih

Lantai lobby menggunakan material kombinasi marmer produksi Solo Marmer. Material ini digunakan karena memberikan suasana yang modern tanpa meninggalkan tema batik tirta intan pari. Tekstur alami pada material marmer juga memberikan kesan dinamis. Kelemahan dari pemilihan material ini terletak pada kerumitan motif marmer yang memerlukan pemesanan khusus sehingga memerlukan biaya yang relatif tinggi. 


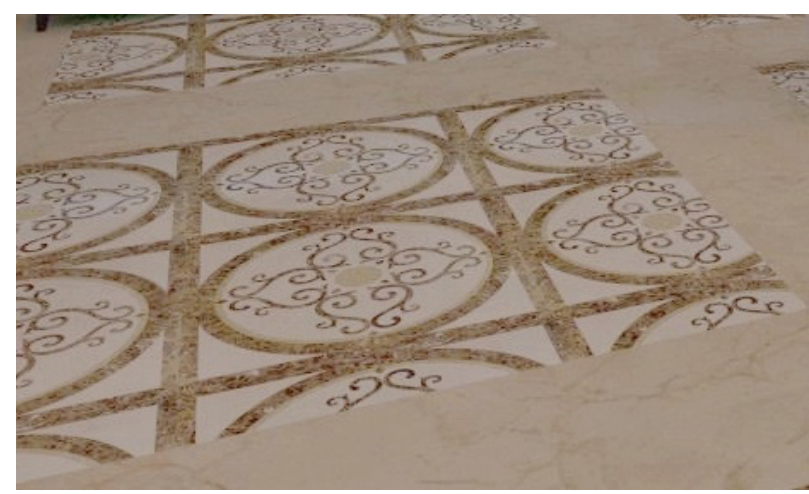

Gambar 5 Lantai Lobby Terpilih

\section{Dinding Lobby Terpilih}

Dinding pada lobby menggunakan material semen aci dengan finishing cat putih, custom marmer cover, lumbersering kayu lapis dan ornamen ukir kayu. Kombinasi material ini memberi suasana pada lobby menjadi lebih menarik dan modern, sesuai dengan gaya postmodern, memberi kesan mewah pada ruangan. Tekstur alami dengan kombinasi warna cat putih memberi kesan dinamis. Kelemahan dari pemakaian material dinding lobby adalah kerumitam motif membutuhkan pemesanan custom, akan tetapi memiliki warna dan tekstur serasi dengan tema batik Tirta Intan Pari, serta perawatan lebih mudah dan praktis.

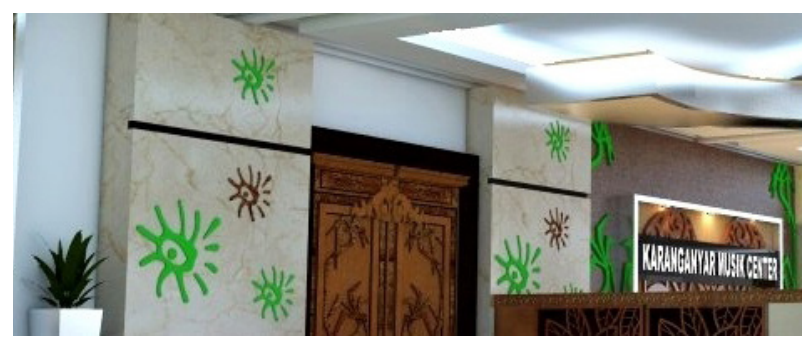

Gambar 6 Dinding Lobby Terpilih

\section{Ceiling Lobby terpilih}

Penutup atap atau ceiling lobby menggunakan material ceiling board, fin: cat putih, ex: Calsi Board, dengan rangka baja ringan dan lis profil gypsum. Sebagai variasi dan ormnamen dipakai bahan dengan warna natural yaitu laminasi kayu (plywood), sehingga memberi suasana pada lobby menjadi lebih menarik, sesuai dengan gaya postmodern yang menonjolkan perpaduan dua kesan. Kerumitam motif membutuhkan pemesanan lis profil gypsum custom dan tukang yang berpengalaman. Warna dan bentuk serasi dengan tema batik Tirta Intan Pari. Perawatan material yang digunakan tergolong mudah dan praktis, karena material relatif tahan air dan kelembapan udara.

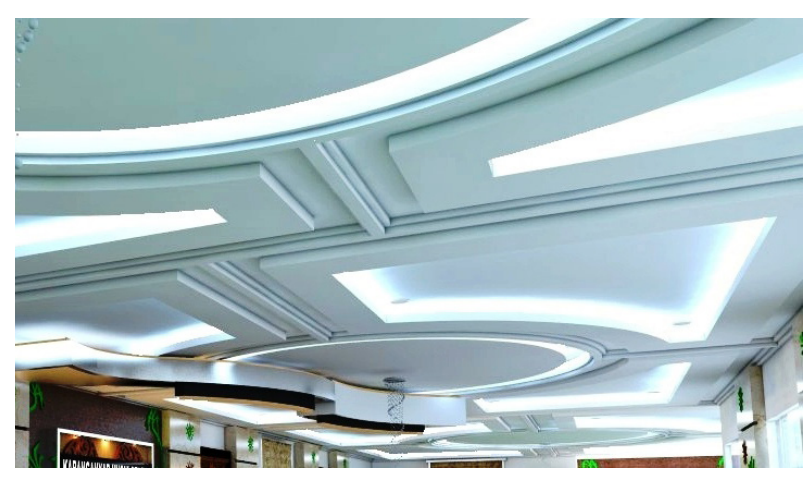

Gambar 7 Ceiling Lobby Terpilih

\section{Pengisi ruang Lobby Terpilih}

Pengisi ruang pada Lobby menggunakan meja resepsionis dengan material plywood, marmer dan ornamen ukir kayu, pemilihan meja resepsionis ini didasarkan pada bentuk menarik, fungsional dan sesuai dengan tema batik Tirta Intan Pari. Kursi resepsionis menggunakan material fiber hitam pada dudukan dan sandaran, dilengkapi dengan armrest serta penyetel kemiringan dan ketinggian, juga dilenglapi dengan roda pada kaki, kursi ini dipilih karena ergonomis dan praktis sebagai kursi kerja. Sofa tunggu menggunakan material custom dengan pelapis oscar kombinasi putih dan hijau, mudah dalam perawatan dan sesuai dengan warna batik Tirta Intan Pari, meja kaca dengan rangka stainless steel terlihat bersih dan menarik. Meja security menggunakan material plywood, marmer dan ornamen ukir kayu, meja ini dipilih karena bentuk yang menarik dan fungsional, 
serta warna dan ornamen yang sesuai dengan tema batik Tirta Intan Pari. Kursi security yang dipilih menggunakan material fiber hitam pada dudukan dan sandaran, dilengkapi dengan armrest dan juga dilenglapi dengan roda pada kaki, kursi ini dipilih karena ergonomis dan praktis sebagai kursi kerja security.
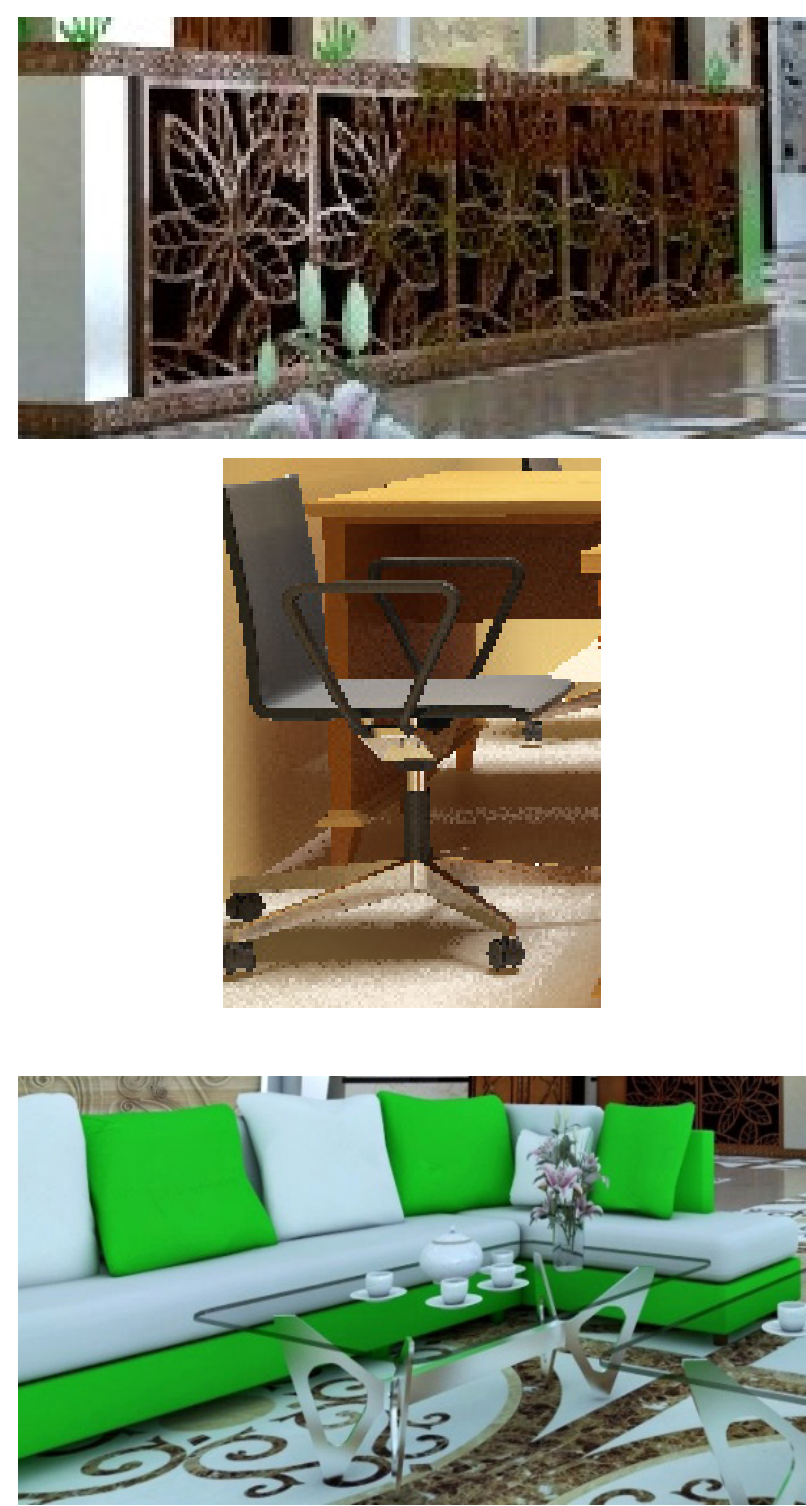

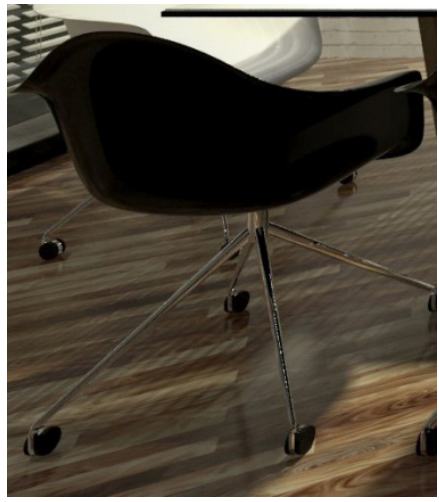

Gambar 8 Pengisi Ruang Lobby Terpilih

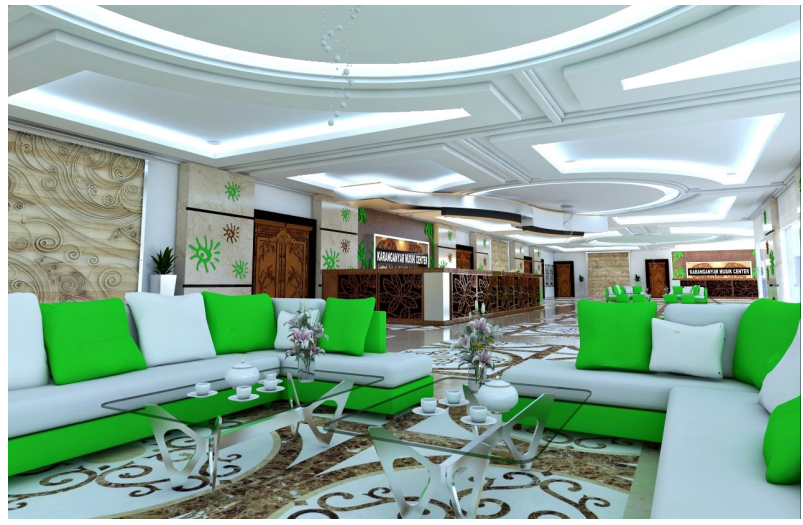

Gambar 9 Perspektif Lobby

\section{E. Hasil dan Pembahasan Area Panggung Musik}

1. Lantai Panggung Musik Terpilih

Lantai menggunakan penutup karpet wall to wall dengan warna abu-abu muda, ex: Good Rich. Penutup lantai karpet membuat suasana panggung musik menjadi lebih menarik dan terkesan mewah. Lanyai karpet juga aman karena tidak licin selain itu proses pemasangan tergolong mudah dan cepat, juga biaya yang tergolong ekonomis. Bahan karpet juga sesuai karena aktivitas panggung merupakan pertunjukan musik tradisional yang memakai peralatan musik yang tergolong berat, seperti misalnya gamelan dan lesung, sehingga bahan pelapis lantai tahan lama karena tidak mudah 
tergores.

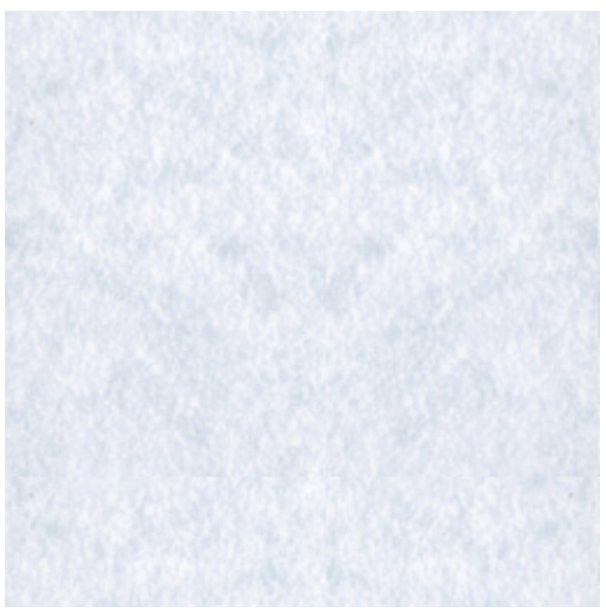

Gambar 10 Lantai Panggung Musik Terpilih

\section{Dinding Panggung Musik Terpilih}

Pernutup dinding area panggung sebagai backdrop permanen menggunakan material dinding semen aci dengan finishing cat putih, marmer, lumbersering kayu lapis, ornamen ukir kayu, LED Panel Screen. Kombinasi material ini memberi suasana pada area panggung musik menjadi lebih menarik, sesuai dengan gaya postmodern yang menonjolkan dua kesan material, dan memberi kesan mewah pada ruangan. Tekstur alami dengan kombinasi warna cat putih memberi kesan dinamis. Kelemahan pemakaian material ini adalah kerumitam motif membutuhkan pemesanan custom, akan tetapi warna dan tekstur serasi dengan tema batik Tirta Intan Pari dan perawatan lebih mudah dan praktis, sehingga biaya maintenance tergolong rendah.

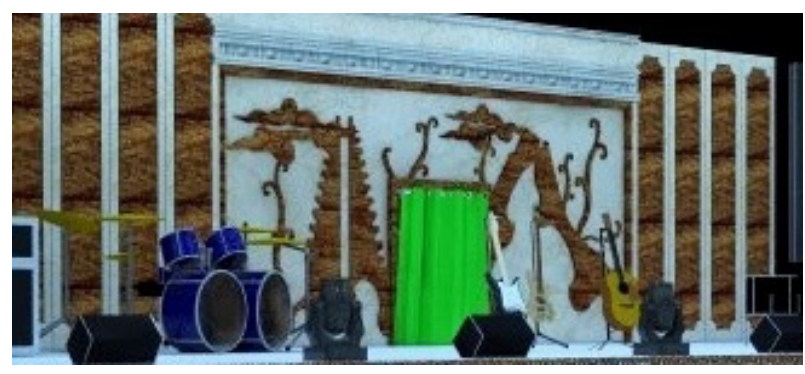

Gambar 11 Dinding Panggung Musik Terpilih

\section{Ceiling Panggung Musik terpilih}

Material ceiling pada area panggung musik menggunakan Ceiling board, fin: cat putih, ex: Calsi Board, Alumunium composite panel, ex: Seven, black gloss, dengan rangka baja ringan, dan pemakaian lis gypsum. Pemakaian rangka baja ringan dengan standar SNI ex EKG bertujuan agar ceiling mampu menyangga beban rigging yang akan dipasang ketika ada pertunjukan sebagai penggantung lampu panggung ataupun suond system tambahan. Perpaduan material memberi suasana pada area panggung musik menjadi lebih menarik, mewah dan bersih. Material lebih tahan air dan awet, warna dan bentuk serasi dengan tema batik Tirta Intan Pari dan perawatan lebih mudah dan praktis.

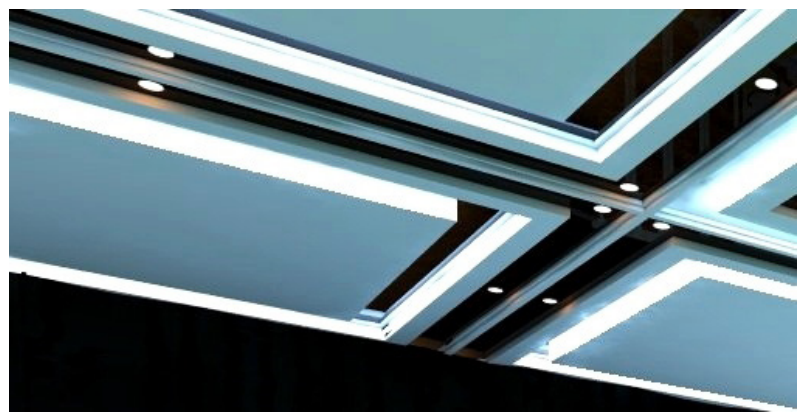

Gambar 12 Ceiling Panggung Musik Terpilih

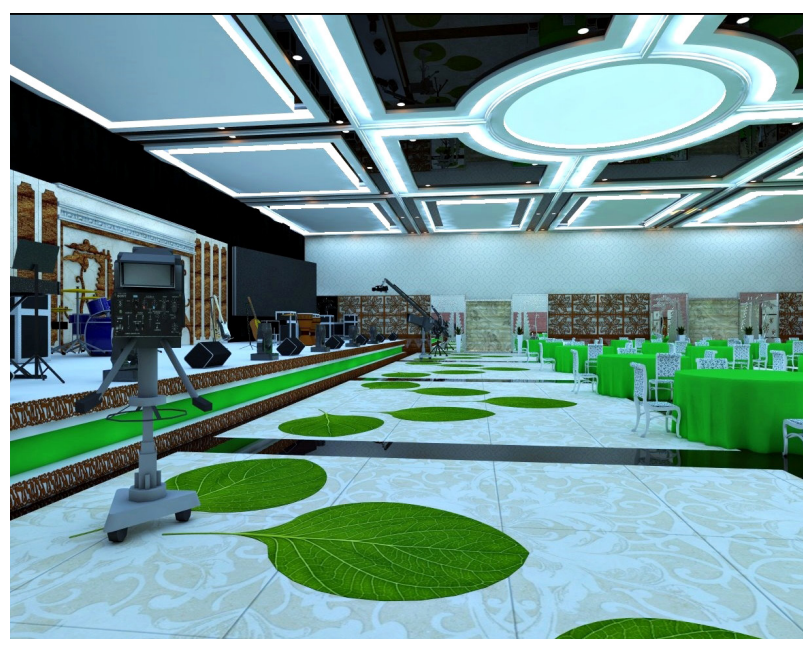

Gambar 13 Perspektif Area Panggung Musik 


\section{F. Hasil dan Pembahasan Area Cafe}

1. Lantai Cafe Terpilih

Lantai area cafe menggunakan material custom marmer, ex: Solo Marmer, material ini memberikan suasana mewah dan dinamis. Motif lantai mengambil bentuk dari motif batik tirta intan pari, sehingga mendukung tema yang diusung pada aera cafe. Tingkat keawetan material yang tergolong tinggi sesuai dengan aktivitas area cafe yang merupakan ruang publik dengan pengguna yang banyak dan beragam. Kelemahan dari material ini adalah kerumitan motif yang memerlukan pemesanan custom dan harga yang relatif tinggi.

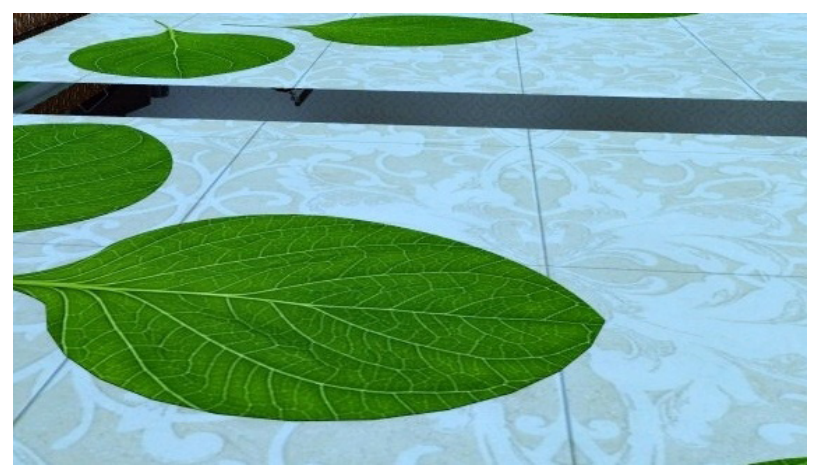

Gambar 14 Lantai CafeTerpilih

\section{Dinding Cafe Terpilih}

Material dinding area cafe menggunakan beberapa material, yaitu dinding semen aci dengan finishing wallpaper, marmer, cermin dengan ornamen stainless steel plat, dan kombinasi ornamen ukir kayu. Perpaduan material ini memberi suasana pada cafe menjadi lebih menarik, sesuai dengan gaya postmodern yang menonjolkan dua kesan etnik dan modern dan memberi kesan mewah pada ruangan. Kelemahan dari pemakaian material ini adalah kerumitam motif membutuhkan pemesanan custom, akan tetapi warna dan bentuk serasi dengan tema batik Tirta Intan Pari, dan perawatan lebih mudah dan praktis sehingga tidak memerlukan banyak biaya untuk maintenance.

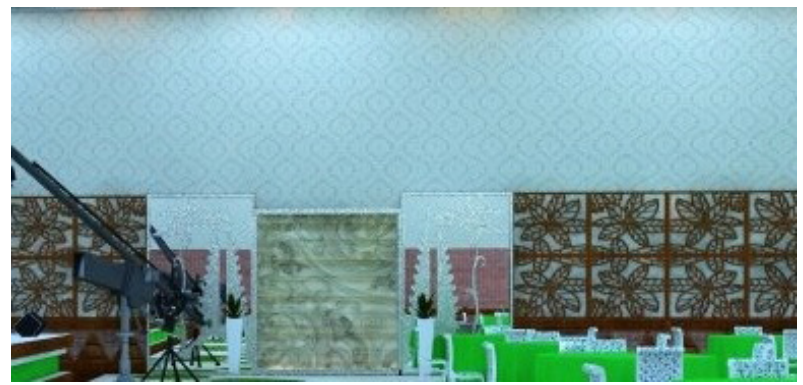

Gambar 15 Dinding CafeTerpilih

\section{Ceiling Area Cafe terpilih}

Material ceiling pada area cafe menggunakan eiling board, fin: cat putih, ex: Calsi Board dan kombinasi materila Alumunium composite panel, ex: Seven, black gloss, pemasangan menggunakan rangka baja ringan, dengan lis profil gypsum. Pemakaian material ini bertujuan memberi suasana pada Souvenir Shop menjadi lebih menarik, memberi kesan mewah dan bersih pada ruangan. Warna dan bentuk serasi dengan tema batik Tirta Intan Pari. Material penutup ceiling ini lebih tahan air dan awet sehingga perawatan lebih mudah dan praktis.

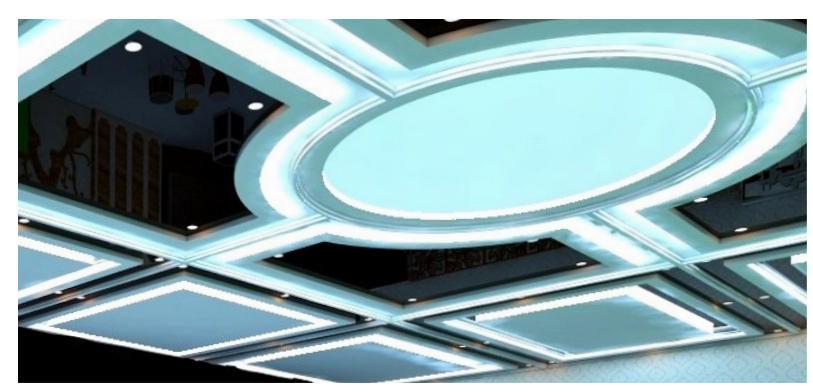

Gambar 16 Ceiling Cafe Terpilih 


\section{Pengisi Area Cafe Terpilih}

Furnitur pada area cafe adalah meja makan dan kursi makan sebagai penunjang aktivitas di area cafe yaitu makan dan minum sembari menikmati sajian pagelaran musik. Meja makan menggunakan material top table plywood, rangka menggunakan besi dengan konstruksi bongkar pasang, penutup kain menggunakan warna hijau. Bentuk menarik fungsional dan sesuai dengan tema batik Tirta Intan Pari. Sementara kursi menggunakan material kayu dengan finishing cat duco putih, kombinasi dengan upholstery motif. Tampak modern tetapi tetap mewakili tema batik Tirta Intan Pari dengan bentuk rangka hasil dari transformasi bentuk air terjun pada batik.

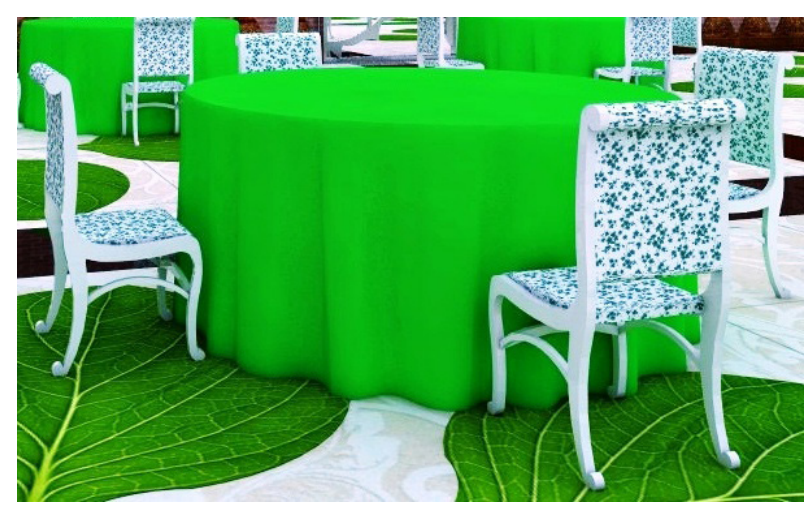

Gambar 17 Pengisi Ruang CafeTerpilih

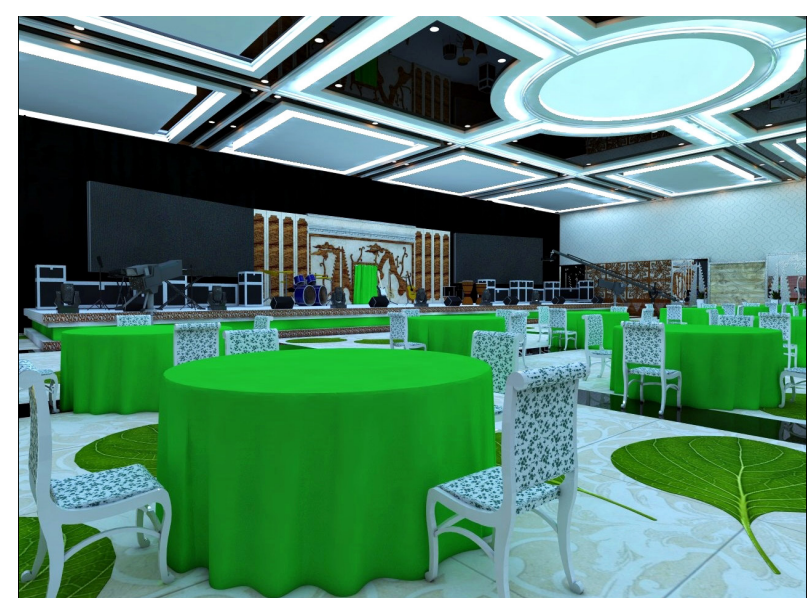

Gambar 18 Perspektif Cafe

\section{G. Hasil dan Pembahasan Souvenir Shop}

1. Lantai Souvenir Shop Terpilih

Kombinasi material granit, ex Solo Marmer dan parquet jati, ex:Teka dipilih sebagai lantai Souvenir Shop karena memberikan suasana yang hangat, mewah, dan sekaligus modern. Warna granit putih dan parquet jati dan bentuk perpaduan material sesuai dengan tema batik tirta intan pari. Kelemahan dari material ini adalah kerumitan motif yang memerlukan pemesanan custom dan harga yang relatif tinggi.

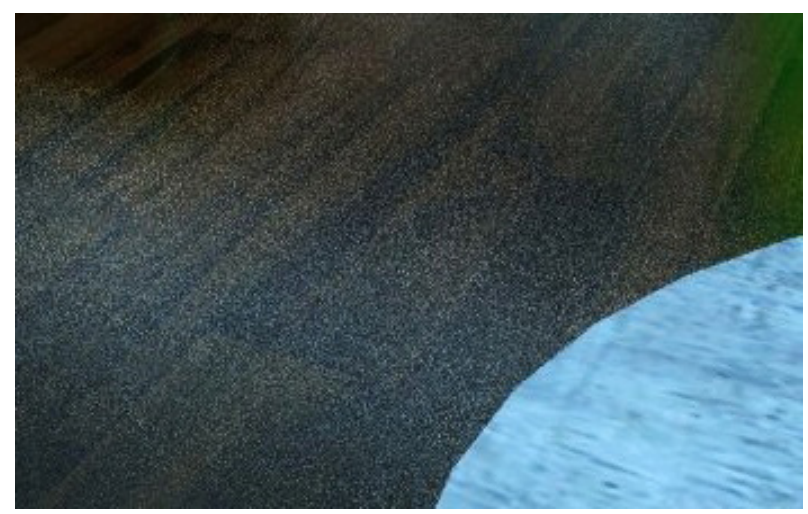

Gambar 19 Lantai Souvenir Shop Terpilih

2. Dinding Souvenir Shop Terpilih

Material dinding pada area Souvenir Shop menggunakan perpaduan beberapa material yaitu dinding bata ekspose, granit, cermin dan tempered glass dengan ornamen stainless steel plat, ornamen acrilycs dengan finishing cat duco. Material yang digunakan memberi suasana pada Souvenir Shop menjadi lebih menarik, sesuai dengan gaya postmodern yang menonjolkan dua kesan etnik dan modern selain memberi kesan mewah dan dinamis pada ruangan. Kelemahan dari pemakaian material ini adalah kerumitam motif membutuhkan pemesanan custom, akan tetapi warna dan bentuk serasi dengan tema batik Tirta Intan Pari, dan perawatan lebih mudah dan praktis sehingga tidak memerlukan banyak biaya untuk maintenance. 


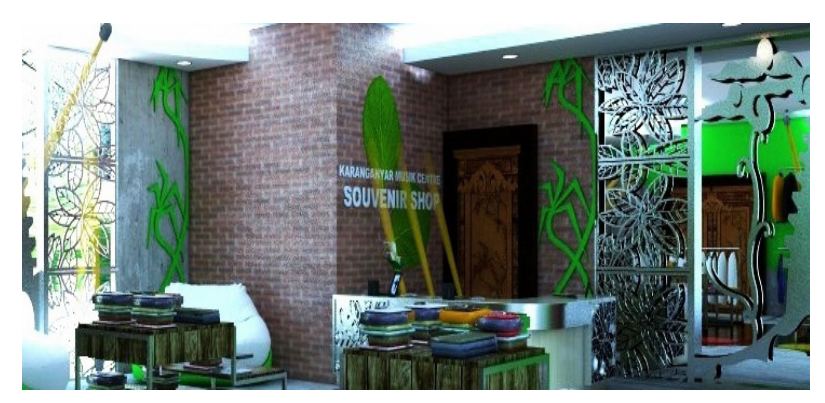

Gambar 20 Dinding Souvenir Shop Terpilih

\section{Ceiling Souvenir Shop terpilih}

Material yang digunakan adalah ceiling board, fin: cat putih, ex: Calsi Board, dengan pemasangan rangka baja ringan dan lis profil gypsum. Pemakaian material ini bertujuan memberi suasana pada Souvenir Shop menjadi lebih menarik dan memberi kesan mewah dan bersih pada ruangan. Warna dan bentuk serasi dengan tema batik Tirta Intan Pari. Material penutup ceiling ini lebih tahan air dan awet sehingga perawatan lebih mudah dan praktis.

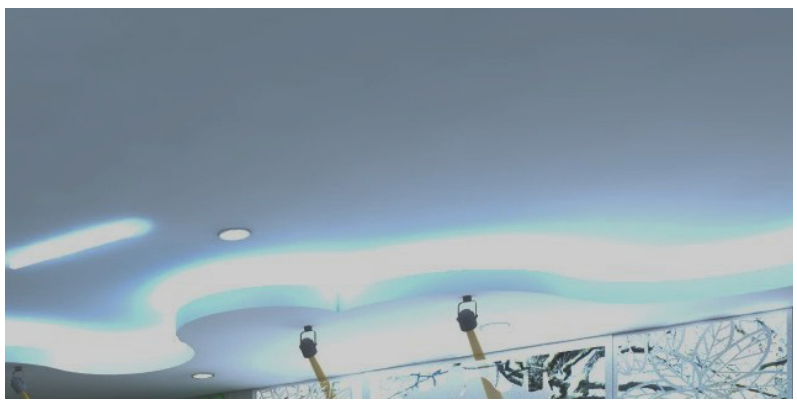

Gambar 21 Ceiling Souvenir Shop Terpilih

\section{Pengisi ruang Souvenir Shop Terpilih}

Pengisi ruang pada Souvenir Shop terdiri dari beberapa furniture yang sesuai dengan aktivitas sebagai sarana penjualan Souvenir. Meja kasir menggunakan material kayu mindi yang difinishing natural sebagai top table, kombinasi dengan lis dan ornamen stainless steel. Serasi dengan tema batik Tirta Intan Pari dan gaya postmodern. Harga relatif lebih mahal karena kerumitan pengerjaan ornamen dari bahan stainless steel. Rak display Souvenir menggunakan material kayu mindi sebagai top table dan rangka pipa stainless steel. Kombinasi bahan sesuai dengan tena batik Tirta Intan Pari. Bentuk fungsional dan praktis. Rak display pakaian menggunakan material alumunium dengan finishing fancy brown satin. Material fungsional, awet dan ringan. Sofa tunggu menggunakan material kayu solid sebagai rangka, dengan lapisan foam dan oscar kombinasi warna putih dan hijau. Mudah dalam perawatan dan lebih sesuai dengan tema ruang.
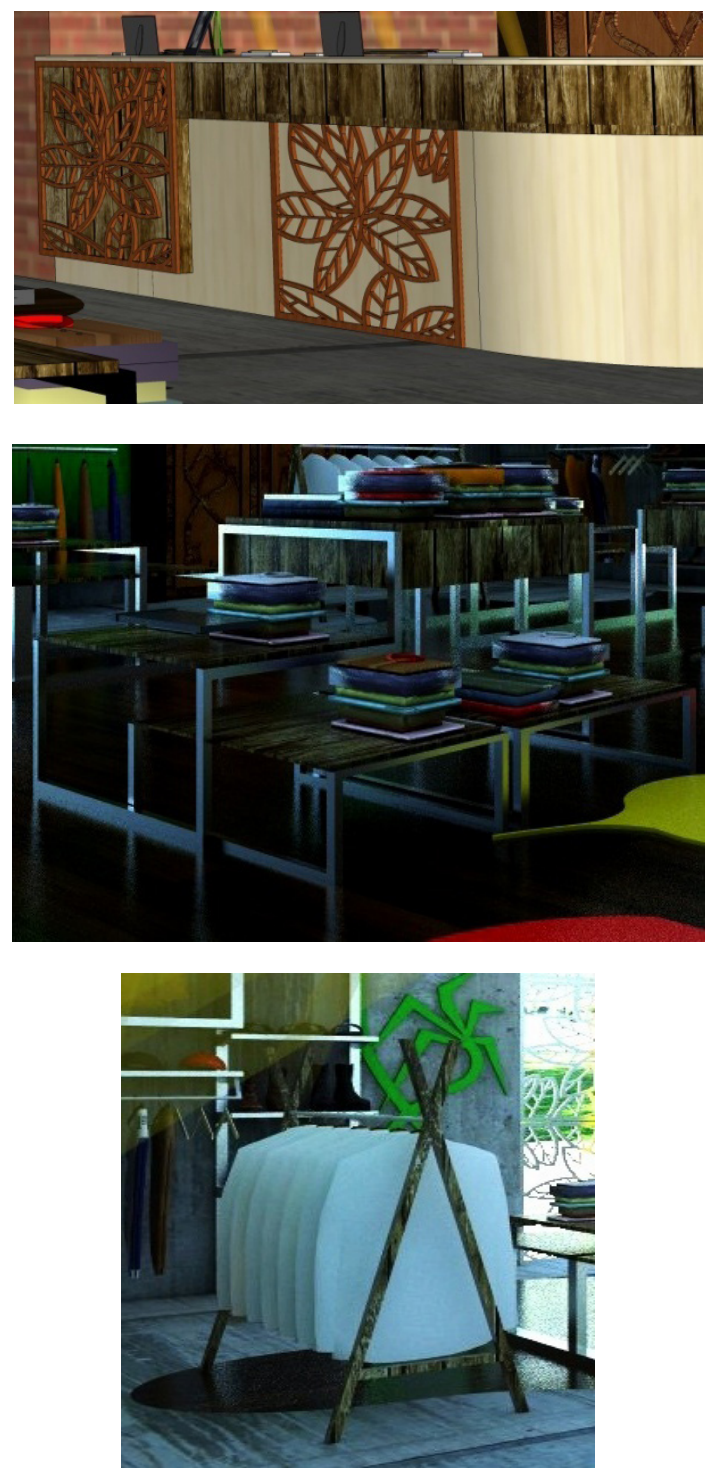


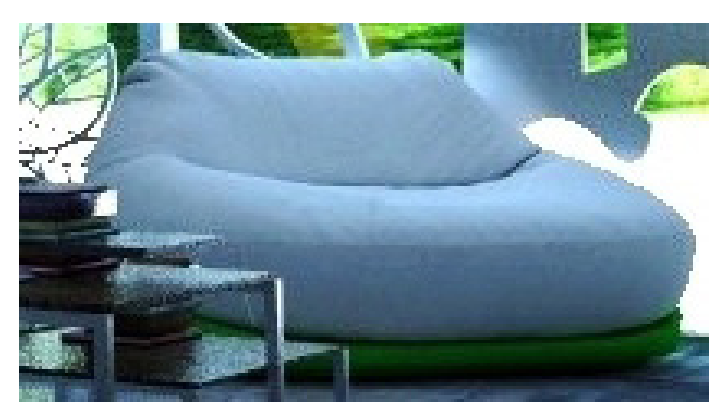

Gambar 22 Pengisi Ruang Souvenir Shop Terpilih

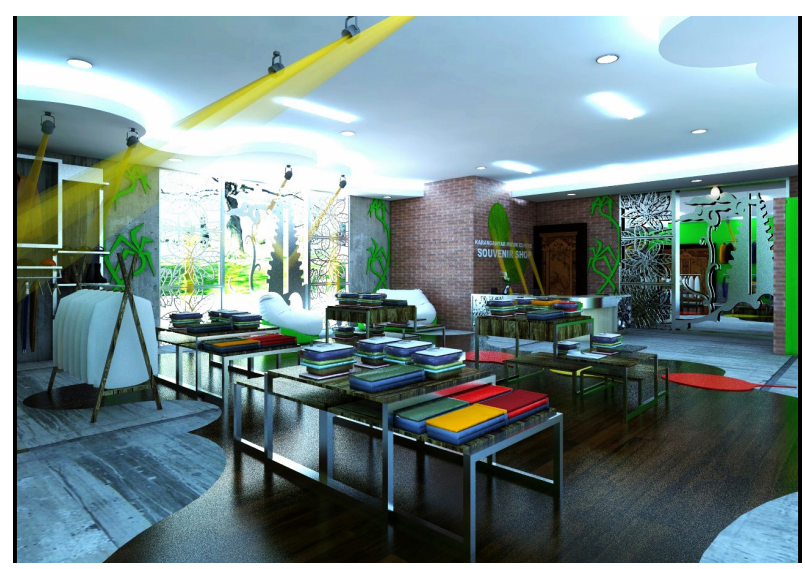

Gambar 23 Perspektif Souvenir Shop

\section{H. Hasil dan Pembahasan Ruang Ganti Artis}

1. Lantai Ruang Ganti Artist Terpilih

Lantai lobby menggunakan material kombinasi marmer produksi Solo Marmer. Material ini digunakan karena memberikan suasana yang modern tanpa meninggalkan tema batik tirta intan pari. Tekstur alami pada material marmer juga memberikan kesan dinamis. Kelemahan dari pemilihan material ini terletak pada kerumitan motif marmer yang memerlukan pemesanan khusus sehingga memerlukan biaya yang relatif tinggi.

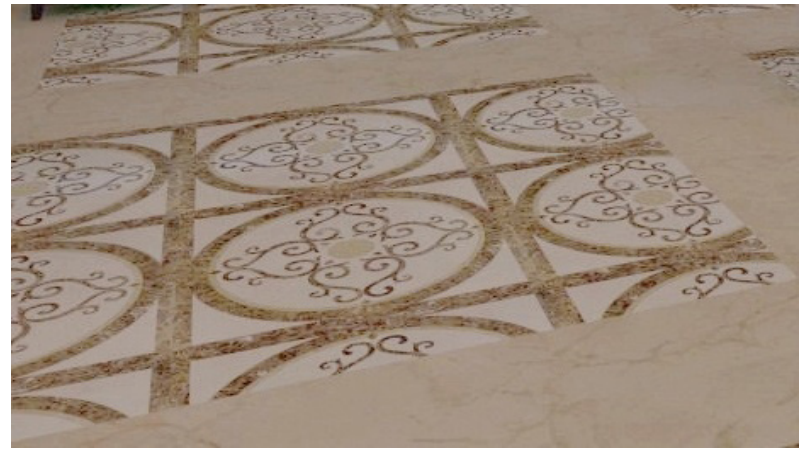

Gambar 24 Lantai Ruang Ganti Artist Terpilih

2. Dinding Ruang Ganti Artist Terpilih

Dinding pada ruang ganti artis menggunakan perpaduan beberpa material yaitu, dinding semen aci dengan finishing cat putih, batu andesit, cermin dengan ornamen stainless steel plat dan ornamen ukir kayu. Perpaduan material ini ditujukan untuk memberi suasana pada Souvenir Shop menjadi lebih menarik, sesuai dengan gaya postmodern yang menonjolkan perpaduan dua kesan dan memberi kesan mewah pada ruangan. Warna dan bentuk sudah sesuai dengan tema batik tirta intan pari yang digunakan sebagai tema perancangan. Kelemahan dari penggunaan material ini adalah kerumitam motif ukir kayu membutuhkan pemesanan custom.

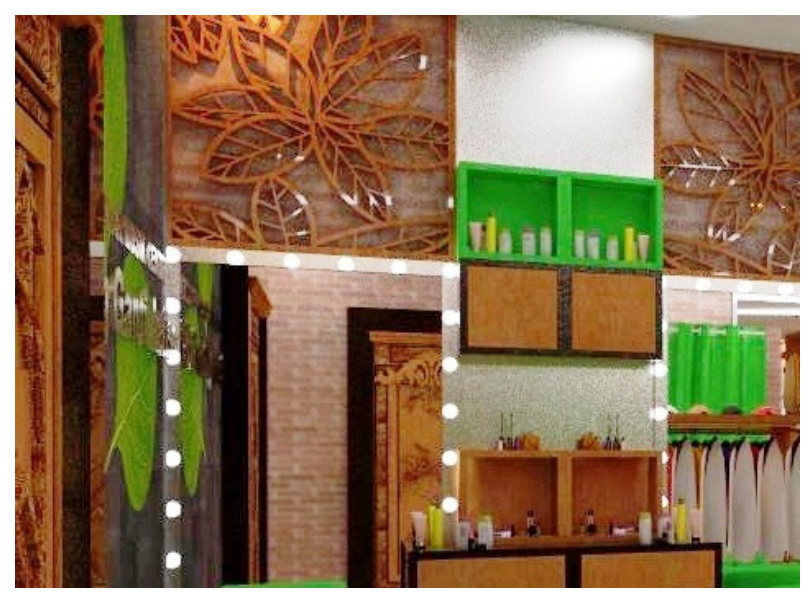

Gambar 25 Dinding Ruang Ganti Artist Terpilih 


\section{Ceiling Ruang Ganti Artist terpilih}

Pada ruang ganti artist material yang dipakai sebagai penutup ceiling adalah ceiling board, fin: cat putih, ex: Calsi Board dengan pemasangan rangka baja ringandan lis profil gypsum, penerapan tema batik tirta intan pari terlihat pada ornamen kayu lapis yang ditempelkan pada ceiling. Pemakaian material ini bertujuan untuk memberi suasana pada Souvenir Shop menjadi lebih menarik dan memberi kesan mewah dan bersih pada ruangan. Material lebih tahan air dan awet, sehingga perawatan lebih mudah dan praktis.

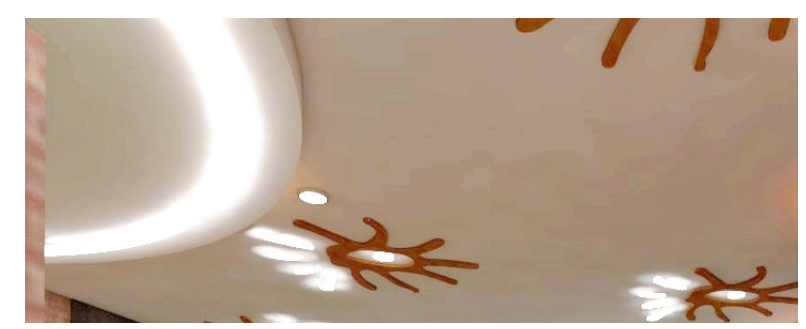

Gambar 26 Ceiling Ruang Ganti Artist Terpilih

\section{Pengisi ruang Ruang Ganti Artist Terpilih}

Furnitur pada ruang ganti artis antara lain adalah set meja rias yang menggunakan material stainless steel sebagai bingkai cermin. Rak make up menggunakan bahan plywood dengan lapisan veneer. Kursi menggunakan rangka kayu dan pelapis oscar kombinasi hijau. Kombinasi material sesuai dengan tema batik Tirt Intan Pari. Alamari wardrobe Menggunakan material kayu jati dengan finishing natural dan kombinasi ornamen acrilycs dengan finishing cat duco hijau. Menampilkan warna dan ornamen yang mendukung tema batik Tirta Intan Pari dengan bentuk fungsional dan efisien. Sofa tunggu menggunakan material kayu solid sebagai rangka, dengan lapisan foam dan oscar kombinasi warna putih dan hijau. Mudah dalam perawatan dan lebih sesuai dengan tema ruang.
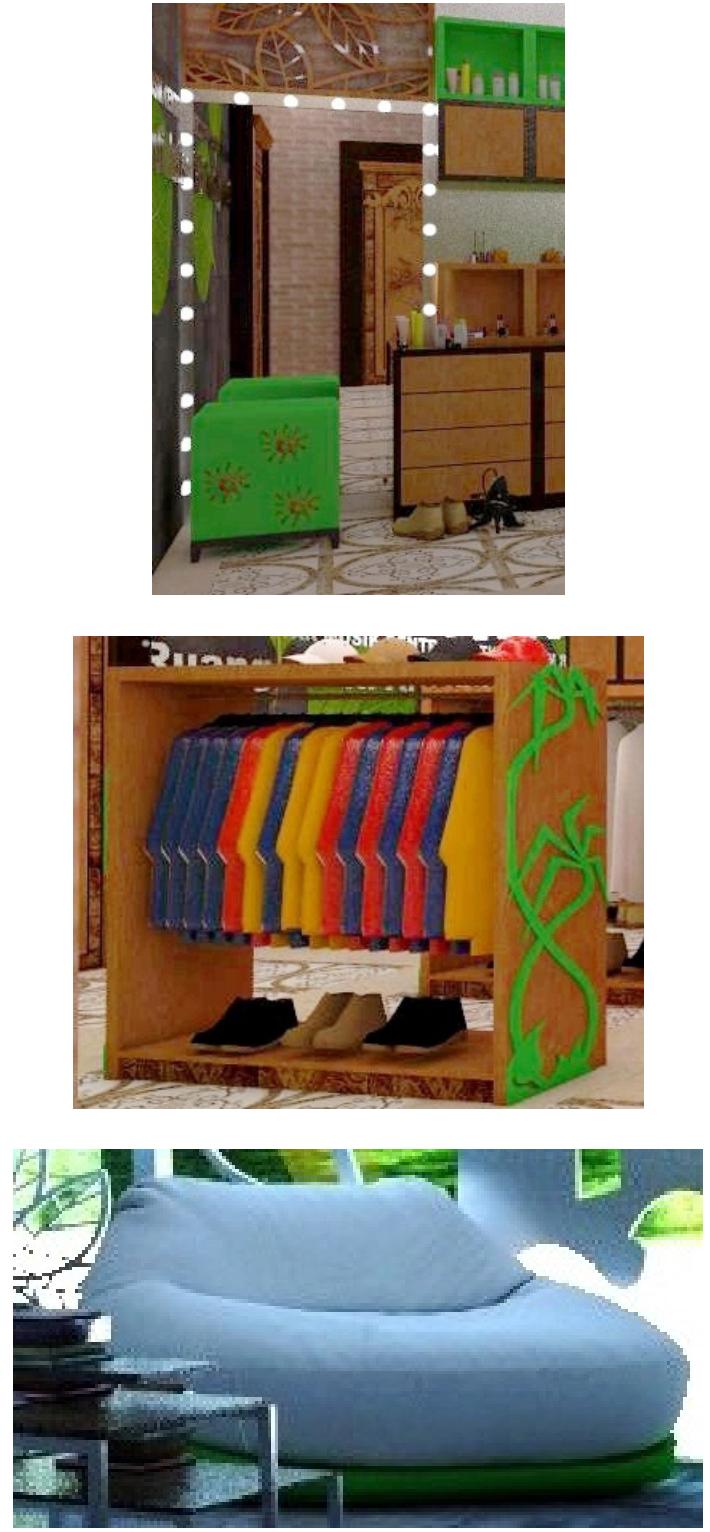

Gambar 27 Pengisi Ruang Ruang Ganti Artist Terpilih 


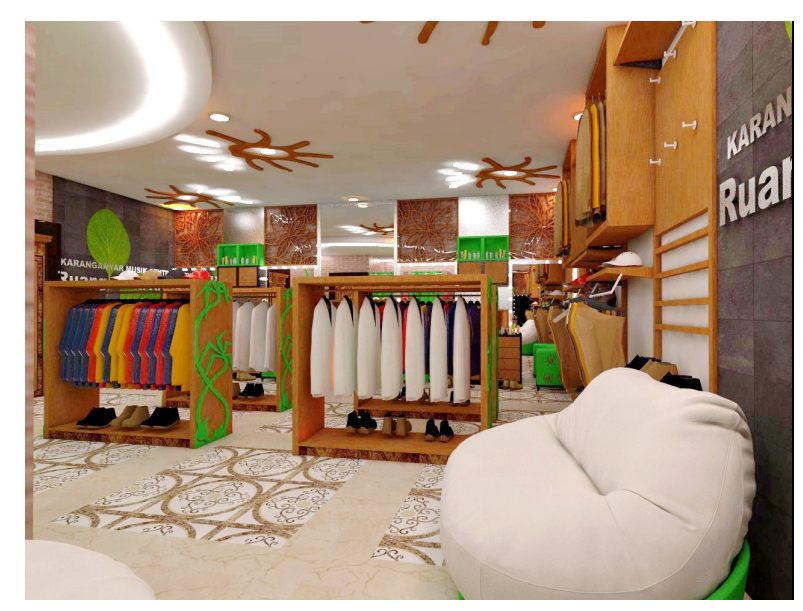

Gambar 28 Perspektif Ruang Ganti Artist

\section{SIMPULAN}

Dasar perencanaan interior Music Centre di Kabupaten Karanganyar dilatar belakangi atas dasar berbagai kebutuhan, diantaranya adalah tempat pertunjukan kesenian music tradisional yang tergabung di bawah Dinas Pariwisata dan Kebudayaan Kabupaten Karanganyar, memerlukan sarana yang mengakomodasi penikmat music dan wisatawan yang ingin menikmati pertunjukan music tradisional khas Kabupaten Karanganyar. Perancangan Interior Music Centre di Kabupaten Karanganyar ini mempunyai sasaran desain yaitu untuk para anggota komunitas seni music di Kabupaten Karanganyar, wisatawan domestic, wisatawan mancanegara, maupun masyarakat umum yang menyukai kesenian music khas Kabupaten Karanganyar yang berkunjung ke Kabupaten Karanganyar.

Perancangan interior Music Centre di Kabupaten Karanganyar ini akan mengangkat tema batik khas Kabupaten Karanganyar, yaitu motif batik Tirta Intan Pari sebagai simbolisme identitas Kabupaten ini yang dikemas dengan gaya postmodern.aplikasi desain interior Karanganyar Music Center didasarkan pada pendekatan fungsi, ergonomi, tema serta gaya. Pendekatan ini dimaksudkan agar desain yang dicapai merupakan desain yang tidak hanya estetis dan nyaman, namun juga berfungsi dengan maksimal sehingga dapatmempermudah manusia saat beraktivitas di dalamnya. Pada hasil desain, terkait dengan tema batik tirta intan pari, maka skema warna yang digunakan secara garis besar adalah warna putih, hitam, hijau, dan cokelat. Penerapan skema warna ini diterapkan menggunakan berbagai material, diantaranya marmer, granit, berbagai jenis kayu, stainless steel, ceiling board, alumunium composite panel, dengan finishing natural clear maupun pewarnaan dengan cat dinding, cat duco, maupun dengan bahan pelapis seperti wallpaper, upholstery, dan kulit sintetis (oscar).

Adapun ruang lingkup garap pada perancangan Karanganyar Music Centre ini adalah sebagai berikut:

1. Lobby (resepsionis, ticketing, ruang tunggu, security center), sebagai sarana informasi bagi pengunjung.

2. Area Panggung Musik, sebagai wadah berlangsungnya pementasan musik tradisional Kabupaten Karanganyar.

3. Area Cafe, sebagai sarana menikmati pertunjukan musik, makan, dan minum bagi pengunjung.

4. Souvenir Shop, sebagai sarana penjualan Souvenir khas Kabupaten Karanganyar.

5. Ruang Ganti Artist, sebagai sarana persiapan artist sebelum melakukan pertunjukan. 


\section{DAFTAR ACUAN}

\section{Buku:}

Angrayni Wulan Idha Pratiwi. "Keroncong Music Centre di Surakarta”. Karya Tugas akhir. Surakarta: FSSR UNS

John M. Echols dan Hasa Shadily. Kamus Inggris Indonesia

J Pamudji Suptandar. 1999. Desain Interior Pengantar Merancang Interior Untuk Mahasiswa Desain dan Arsitektur. Jakarta: Djambatan

Sedyawati, Edy. 1992. Pertumbuhan Seni Pertunjukan. Jakarta: Sinar Harapan

Surat Kabar Harian Joglosemar. 2014. Edisi sabtu, 11/10/2014

\section{Internet :}

http. www.karanganyarkab.go.id/geografi/. 16 September 2017

Etzell Caster, “Arsitektur Postmodern”, diakses dari http://www.academia. edu/8401812/Arsitektur_Post_Modern, pada tanggal 29 Mei 2017 pukul 20.52.

http.www.karanganyarkab.go.id/category/ pariwisata/seni-budaya-pariwisata/. 21 September 2017

http.www.maps.google.com, pada tanggal 28 Agustus 2017 pukul 15.40

M. Qomar.2014. Konsep Motif Batik Tirta Intan Pari. Karanganyar: Dokumentasi Pemerintah Kabupaten Karanganyar 